\title{
Phytochemicals and their role in curing fatal diseases: A Review
}

\author{
Azmatullah Khan ${ }^{1,2^{*}}$, Muhammad Suleman ${ }^{1}$, Abdul Baqi ${ }^{2,3}$, \\ Samiullah $^{3}$ and Muhammad Ayub ${ }^{1}$ \\ 1. Institute of Biochemistry, University of Balochistan, Quetta 87300-Pakistan \\ 2. Colleges, Higher and Technical Education Department, Balochistan, Quetta-Pakistan \\ 3. Department of Chemistry, University of Balochistan, Quetta 87300-Pakistan \\ *Corresponding author's email: azmatullahkakar@gmail.com \\ Citation \\ Azmatullah Khan, Muhammad Suleman, Abdul Baqi, Samiullah and Muhammad Ayub. Phytochemicals and \\ their role in curing fatal diseases: A Review. Pure and Applied Biology. Vol. 8, Issue 1, pp343-354. \\ http://dx.doi.org/10.19045/bspab.2018.700193
}

Received: $16 / 10 / 2018 \quad$ Revised: 28/11/2018

Accepted: 30/11/2018

Online First: 01/12/2018

\section{Abstract}

Plants are serving mankind from the first day of his creation and have been a chief source of medicines from thousands of years. According to the latest report of the World Health Organization (WHO), more than eighty percent people are completely relying on the herbal medicines comprised of phytochemicals. These are biologically active, naturally occurring and non-essential nutrients. They are found in fruits (apples, grapes, berries, cherries, citrus fruits peel, apricots, oranges), vegetables (kale, cabbage, cauliflower, carrot, cooked tomato, sweet potato, soybean, bean) green tea, cereals, nuts, whole grains and seeds in a considerable quantity protecting human health from hazards. These compounds are major sources of a large number of medicines consisting of various groups like emetics, antispasmodics, antimicrobials, anti-cancerous etc. In traditional system of medications, large number of plants are considered to have therapeutic characteristics such as anti-pyretic, antioxidant, antibacterial, antidiarrheal, antifungal, anti-inflammatory and antidiabetic. They are extensively used worldwide for the treatment of various kinds of fatal diseases like cancer, neurodegenerative, cardio vascular diseases, type 2 diabetes etc. Various phytochemicals develop the immune system and protect the body from dangerous pathogens. It is believed that there is proper treatment mechanism for each and every disease by the nature in one or another way. Due to this reason, the researchers of the day are stressing to identify the role of these secondary metabolites against various diseases based on phytotherapeutical methods. In this paper, an attempt has been made to highlight the role of several phytochemicals in curing of various fatal diseases.

Keywords: Fatal diseases; Herbs; Medicinal plants; Pathogens; Secondary metabolites

\section{Introduction}

Plants are serving the human beings in number of ways, therefore they are considered as gift from the nature for them. Their effective use as medicine have been reported since written human history. From immemorial times, these are known as constituents of phytomedicine. Wonderful collection of industrial chemicals have also been obtained from plants. These plant based natural chemicals can be extracted from different parts of the plant such as leaves, fruits, flowers, seeds, roots, stems, barks, rhizomes etc. which reveal that each and every part of the plant contain these biologically active components [1]. In recent years, treatments through medicinal plants got tremendous attention worldwide [2]. Several studies of traditional herbal therapies for different diseases have been 
carried out which led to the development of alternative drugs and therapeutic strategies. Since the intake of medicinal plants is increasing day by day, it is interesting to use these plants as supplement in diet. Moreover, these plants may arrange important nutrients and essential elements for living organisms [3-6]. It was a primitive idea to find out the therapeutic power of plants therefore, various plants and herbs were used as drugs on large scale in the pre-historic human civilization [7]. It has been proved that some 60,000 years back Neanderthals, in today's Iraq, used plants like hollyhock for the cure of different ailments. Even today, these herbs are extensively used in ethnomedicine throughout the world. Earlier Indian, Chinese and North African civilizations established the medicinal importance of a number of plants while curing various fatal diseases [8].

In late $19^{\text {th }}$ century, an invention was made when therapeutics float a plan to segregate bioactive compounds from analeptic plants. With the help of this idea, the most famous anti-malarial drug, quinine was prepared from the barks of cinchona tree by two French scientists, Caventou and Pelletier, which showed to be innovative in the field of phyto-remediation [9]. In the year 2002, World Health Organization (WHO) reported that nearly eighty percent people all over the world in developing and nondeveloping nations depend on these herbal prescriptions to cater the need of their primary health care [10]. Due to lack of health experts, deficient health facilities and shortage of medicines, herbal drugs obtained from medicinal plants got considerable importance nowadays due to their antibacterial, antimalarial, antipyretic, pain-relieving, anti-inflammatory, antiviral, anticancer, cytotoxic effects and antifungal activities [11, 12]. These therapeutic properties of medicinal plants are due to the presence of phytochemicals [13].

The biologically active chemical compounds which occur naturally in medicinal plants are referred as phytochemicals. "Phyto or phyton" is a Greek word, means "plant", hence the chemicals obtained from plants are called phytochemicals. These herbal chemicals are non-nutritive so they are regarded as non-essential for the proper life of human beings. Earlier, it was thought they only prevent plants from herbivorous mammals, predators, fungi and harmful insects but later on, it was revealed that they are equally beneficial for the safety of human beings from fatal disorders [14]. Till now, more than twelve thousand phytochemicals have been isolated from various plants. Some very common phytochemicals like flavonoids from fruits, isoflavones from soy and lycopene from tomatoes have been extracted [15]. These bioactive compounds are more effective with no or less side effects [16]. Phytochemicals consist of medicaments which are responsible for plant pigments, aroma, appearance and flavor. Almost fifty percent communities of the world trust on herbal medicines as these are safe and beneficial. During the period of 1984-1995, out of 522 advanced medicines, approximately $39.5 \%$ were synthesized from medicinal plants. In the very beginning of $21^{\text {st }}$ century, a study was conducted revealing that round about $61 \%$ of all drugs were derived from plant sources. Besides this, 08 out of 30 highly marketed medicines were obtained from natural sources [17]. These biologically active compounds act as synergistic agents which allow nutrients to be utilized by living organisms more efficiently. They shield plants from severe environmental hazards like pollution, drought, stress, pathogenic attacks and ultraviolet exposure. These include flavonoids, quinines, terpenoids, oils, lignins, resins, saponins, alkaloids, phenolic acids, tannins, phytosterols, cardiac glycosides, stilbenes, coumarins etc. as secondary metabolites whereas chlorophyll, common sugars and proteins are regarded as primary metabolites $[18,19]$. These compounds are solely responsible for color and 
organoleptic properties of plants. In many areas, they are easily approachable as a dietary accessory but dormant health advantages of phytochemicals are only reachable from the utilization of complete plant. Anti-nociceptic activities are the momentous properties of conventional medicinal plants against a number of pathogens [20].

Recently, plants bioactive organic compounds became of immense importance due to their vibrant role and adaptable applications in curing fatal diseases. Medicinal plants are not only the richest bio-source of drugs in ancient era but also equally applicable in modern age as food supplements, nutraceuticals, folk medicines, pharmaceutical intermediates etc. [21]. These are non-nutritive plant chemicals with disease preventative properties. They are considered as nonsupportive nutrients for the proper sustainability of life [22].

\section{History of phytochemicals}

Since the existence of plants, bioactive compounds occur in them. However, they have been recognised for hundred years regarding their reality. Being the main source of phytochemicals, herbal plants are conventionally used throughout the world.

It has been believed that the awareness about old-fashioned medicines established through trial and error concept over centuries. As per available record, Chinese own the oldest medicine and treatment system in the world. Over and above five thousand years ago, the Chinese utilized their drugs due to the effects of "yang" and "yin", and on the 05 constituents. Previously, herbal medicines date back to some 2800 BC when the Chinese emperor "Shen Nong" wrote the book "The Great Native Herbal". Likewise, the great scientists Aristotle (384-322 BC) and Hippocrates (460-377 $\quad$ BC) introduced herbal medicines for curing of fatal diseases for the first time. During 1800-1900, the fundamental goal of the investigators was to unearth the active compounds that had pesticidal or medicinal properties for instance, morphine, salicylic acid and pyrethroids (pesticides). During 1980s, many laboratories were established to find out phytochemicals in plants which will be used as medicines. Many of these discovered phytochemicals used to treat illnesses and other infections such as cancer, heart attack and stroke. Meanwhile, other scientists conducted epidemiological study to find out the relationship between the usage of special phytoconstituents and man life. Recent studies revealed that daily diet, rich in dietary plants, can minimize the danger of chronic diseases like cardio vascular illnesses, type 2 diabetes, neurodegeneration, tumour growth and cancer of different types to a greater extent.

\section{Importance of phytochemicals}

Researchers have recognized more than twelve thousands of various phytochemicals present in nuts, fruits, whole grains, beans, seeds and vegetables in a reasonable quantity. It has been reported that eating fruits, rich in phytochemicals, in maximum quantity may help in preventing at least one in every five $(20 \%)$ cases of cancer along with other serious illnesses like heart disease. Phytochemicals are supportive in the prevention and healing of following infections and illnesses.

1. Phytochemicals stimulate the body's immune system against various diseases causing agents like bacteria, fungi, viruses, etc.

2. Inhibit the potential for cancer causing substances (carcinogens) which are formed in the body due to the substances we take from the environment in the form of food or beverages.

3. Diminish oxidation, the damage of cells that arises with aging and exposure to pollution. Free radicals are accountable for oxidation which leads to the formation of irregularities in cell and resultantly may lead to cancer.

4. Slow the growing rate of cells which can cause cancer.

5. Reduce tenderness which causes cancer growth. 
6. Activate death (apoptosis process) of injured cells that may be a forerunner to cancer.

7. Not only stop the damage in DNA but also useful in its repair mechanism.

8. Accommodating in the regulation of hormones like insulin and estrogen in the body. The excess level of these hormones will increase the danger of colon and breast cancer [23].

Recently, the application and exploration for plants based dietary supplements and medicines are more accelerated than past. The biochemists, microbiologists, botanists and ethnopharmacologists are rigorously searching for phytochemicals and their development for the curing of chronic illnesses. Traditional naturopaths have long applied medicinal herbs for the prevention of infectious diseases.

As mentioned earlier, phytochemicals are present in fruits, vegetables, various herbs and shrubs and are using from centuries for the treatment of various fatal diseases as shown in (Table 1).

Phytochemicals extracted from various medicinal plants show one or more bioactivities against the competitors, predators, insects and herbivorous mammals. Prominent phytochemicals along with their structural features and important bioactivities are illustrated in (Table 2).

Table 1. Secondary metabolites, their key sources and possible benefits [24].

\begin{tabular}{|c|c|c|}
\hline Secondary Metabolites & Sources & Potential benefits \\
\hline $\begin{array}{l}\text { Flavonoids } \\
\text { (quercetin, anthocyanins) }\end{array}$ & $\begin{array}{c}\text { Onions, coffee, apples, soya } \\
\text { beans, tea, citrus fruits and soy } \\
\text { products. }\end{array}$ & $\begin{array}{l}\text { May constrain inflammation \& } \\
\text { tumor growth. } \\
\text { May help immunity \& boost } \\
\text { production of detoxifying enzymes } \\
\text { in the body. }\end{array}$ \\
\hline $\begin{array}{c}\text { Terpenes } \\
\text { (carnosol, perillyl alcohol, } \\
\text { limonene) }\end{array}$ & $\begin{array}{l}\text { Rosemary, citrus fruits peel, } \\
\text { cherries. }\end{array}$ & $\begin{array}{l}\text { May perform as antioxidant, fight } \\
\text { against viruses, slow growth of } \\
\text { cancerous cells, strengthen } \\
\text { immune system and protect cells } \\
\text { from the danger of cancer. }\end{array}$ \\
\hline $\begin{array}{c}\text { Polyphenols } \\
\text { (resveratrol, ellagic acid ) }\end{array}$ & $\begin{array}{l}\text { Berries, peanuts, green tea, } \\
\text { whole grains, wine, apples, } \\
\text { grapes, citrus fruits. }\end{array}$ & $\begin{array}{l}\text { May work as antioxidants, stop } \\
\text { cancer formation and controls } \\
\text { inflammation. }\end{array}$ \\
\hline $\begin{array}{c}\text { Carotenoids } \\
\text { (zeaxanthin, lycopene, beta } \\
\text { carotene, lutein) }\end{array}$ & $\begin{array}{l}\text { Water melons, apricots, leafy } \\
\text { greens, carrots, oranges, } \\
\text { cooked tomatoes, broccoli, } \\
\text { sweet potatoes, cantaloupes, } \\
\text { red \& green fruits, winter } \\
\text { squashes, vegetables. }\end{array}$ & $\begin{array}{l}\text { May improve immune response, } \\
\text { check growth of cancer cells and } \\
\text { work as antioxidants. }\end{array}$ \\
\hline $\begin{array}{l}\text { Isoflavins } \\
\text { (genistein, daidzein) }\end{array}$ & Soybeans and soy products. & $\begin{array}{l}\text { May check growth of tumor, work } \\
\text { as antioxidant and minimize cancer } \\
\text { related hormones production. }\end{array}$ \\
\hline $\begin{array}{c}\text { Indols and glucosinolates } \\
\text { (sulforaphane) }\end{array}$ & $\begin{array}{l}\text { Vegetables of cruciferous } \\
\text { family like kale, broccoli, } \\
\text { brussels sprouts, cabbages, } \\
\text { cauliflowers, collard greens. }\end{array}$ & $\begin{array}{l}\text { May block carcinogens, inhibit } \\
\text { tumor growth, perform as } \\
\text { antioxidants and induce } \\
\text { detoxification of carcinogens. }\end{array}$ \\
\hline Isothiocyanates & $\begin{array}{l}\text { Cruciferous family vegetables } \\
\text { like kale, broccoli, brussels } \\
\text { sprouts, cabbages, } \\
\text { cauliflowers, collard greens. }\end{array}$ & $\begin{array}{l}\text { May induce detoxification of } \\
\text { carcinogens, check growth of } \\
\text { tumor and perform as antioxidants. }\end{array}$ \\
\hline $\begin{array}{c}\text { Inositol } \\
\text { (phytic acid) }\end{array}$ & $\begin{array}{c}\text { Soy products, nuts, oats, } \\
\text { wheat, soybeans, rice rye, bran } \\
\text { from corn. }\end{array}$ & $\begin{array}{l}\text { May perform as antioxidants \& } \\
\text { slow down cell growth. }\end{array}$ \\
\hline
\end{tabular}


Table 2. Phytochemicals, their structural features along with their bioactivities

\begin{tabular}{|c|c|c|c|}
\hline Phytochemicals & Structural features & Examples & Activities \\
\hline $\begin{array}{c}\text { Phenols \& } \\
\text { Polyphenols }\end{array}$ & $\begin{array}{c}\mathrm{C}_{3} \text { Side chain, -OH groups, } \\
\text { Phenol ring. }\end{array}$ & $\begin{array}{c}\text { Cinnamic acid, } \\
\text { Catechol, Epicatechin. }\end{array}$ & $\begin{array}{c}\text { Antimicrobial, } \\
\text { Antithelamintic, } \\
\text { Antidiarrhoel. }\end{array}$ \\
\hline Quinones & $\begin{array}{c}\text { Aromatic ring, two ketone } \\
\text { substitutions. }\end{array}$ & Hypericin. & Antimicrobial. \\
\hline Tannins & $\begin{array}{c}\text { Polymeric Phenols (Mol. } \\
\text { Wt. 500-3000). }\end{array}$ & Ellagitannin. & $\begin{array}{c}\text { Antimicrobial, } \\
\text { Antithelamintic, } \\
\text { Antidiarrhoel. }\end{array}$ \\
\hline Saponins & Amphipathic glycosides. & $\begin{array}{c}\text { Vina-ginsenosides-R5 } \\
\text { and -R6. }\end{array}$ & Antidiarrhoel. \\
\hline Alkaloids & $\begin{array}{c}\text { Heterocyclic nitrogen } \\
\text { compounds. }\end{array}$ & $\begin{array}{c}\text { Berberine, Piperine, } \\
\text { Palmatine, } \\
\text { Tetrahydropalmatine. }\end{array}$ & $\begin{array}{c}\text { Antimicrobial, } \\
\text { Antithelamintic, } \\
\text { Antidiarrhoel. }\end{array}$ \\
\hline Glycosides & $\begin{array}{c}\text { Sugar \& non carbohydrate } \\
\text { moiety. }\end{array}$ & Amygdalin. & Antidiarrhoel. \\
\hline $\begin{array}{c}\text { Lectins \& } \\
\text { Polypeptides }\end{array}$ & Proteins. & $\begin{array}{c}\text { Mannose-specific } \\
\text { agglutinin, Fabatin. }\end{array}$ & Antimicrobial. \\
\hline
\end{tabular}

\section{Role of phytochemicals in treatment of some fatal diseases}

Phytochemicals are performing vital role in treatment of following ruinous disorders.

\section{Cardiovascular illness}

It is proved that people taking food rich in phytochemicals may face less risk of cardiovascular illness [25]. It is reported that the maximum use of fruits and vegetables in daily diet can minimize the danger of associated cardiovascular illness up to $17 \%$ [26]. Whereas, another study proposed that the per day use of different types of fruits and vegetables rich in phytochemicals would minimize the danger of coronary cardiac disease by $4 \%$. Likewise, some studies were carried out to identify the relationship between the cardiovascular illness and polyphenol rich fruits, the findings were limited but again supported the idea to eat various types of fruits and vegetables on daily basis [27]. A series of studies related to cardiovascular illness and the maximum intake of green and black tea, cocoa and soy products concluded that the consumption of these diets reduces the risk of this lethal disease as these diets are rich in polyphenols and isoflavones respectively. Besides this, reducing inflammation, decreasing the blood clotting tendency, decreasing Low
Density Lipoprotein (LDL) oxidation, lowering blood pressure (BP) and increasing High Density Lipoprotein (HDL) cholesterol are the benefits linked to the excessive consumption of the fruits and beverages rich with phytochemicals [2830]. Cocoa, rich with polyphenols, was found helpful for those whose age was of 50 or more in developing the endothelial function by expanding blood vessels [31]. A comparative study and systematic examination conveyed that the risk of cardiovascular illness minimises by $21 \%$ in those who use 2.5 or more servings of grains as compared to those whose daily intake of whole grains is less than 0.2 servings $[32,33]$. It is also believed that the carotenoids, anthocyanins, lignins, phytosterols and phenolic acids, important constituents of rye, rice, wheat, oats and other grains contribute to protect cardio effects [34]. Lowering of blood pressure, which is very supportive in prevention of cardiovascular illness, is also associated with the quantity of daily intake of whole grains rich with phytochemicals. It drops high blood pressure risk up to $23 \%$ by using more than four servings of whole grains. There is an inverse relationship between the consumption of whole grains and blood pressure means that with the increase in 
consumption of whole grains, the blood pressure will be decreased and vice versa [35]. Through intervention studies, it is found that there is a positive relationship between blood pressure and the daily intake of whole grains $[36,37]$.

\section{Cancer}

Numerous kinds of cancer like colon, breast and lungs have been linked with the daily intake of vegetables, whole grains and fruits [38-40]. A systematic and logical analysis of twenty five potential studies revealed that the daily intake of more than three servings of whole grains lower the colorectal cancer risk up to $17 \%$ [41]. The cancer risk reduction percentage related to the daily consumption of vegetables, grains and fruits was not the same but varied from study to study [42]. These studies have also focused the daily intake of particular phytochemicals and originated a connection to reduce the risk of cancer [43]. A previous research proved that certain flavonoid subclasses were linked with minimum risk of breast cancer. Other studies demonstrated that the diet rich in many phytochemicals was strong in cancer risk reduction as compared to the diet containing less number of phytochemicals [44].

It has been found that the maximum daily consumption of vegetables of family cruciferae like cauliflower, broccoli and cabbage are linked with reduced danger of various types of cancer such as colon, prostrate, breast and lungs [45]. Isothiocyanate particularly sulforaphane phytochemicals are found in the members of family cruciferae such as broccoli are supposed to check the growth of cancer cells. It is clear that the therapeutic mixtures of nutrients rich in secondary metabolites will be operative in the prevention and treatment of cancer. There is sign that the effects of phytochemicals varies regarding cancer's risk from person to person associated with the genetic makeup and age. Depending on menopausal status and genetics, for instance, Isoflavones have estrogen like properties and may rise or decline the possibilities of breast cancer [46]. Few secondary metabolites like sulforaphane, resveratrol, genistein, curcumin and quercetin may boost up the efficiency of chemotherapeutic agents, used for the treatment of cancer [47-49]. Latest research showed that phytochemicals present in tea i.e. polyphenols are very effective in the prevention of cancer of mammary gland, skin, prostrate, lung, gallbladder, oral cavity, colon, oesophagus, small intestine, stomach, pancreas and liver $[50,51]$. Black and green tea polyphenols have been publicised to change or modify gene regulation and also affect the replication of cancer cell and tumour suppression. Usually, catechin, polyphenols of tea, are solely credited for these effects. However, research studies have not established a clear and vibrant association in human beings. The dearth of a reliable effect in human beings could be due to the genetic diversity, inaccurate quantity of tea intake and the nonconsuming of comparatively larger dose used in animal studies [52]. In laboratory research, the polyphenols present in cocoa have been originated to restrict the cancer cell's progression, initiation and promotion. As black chocolate is full of polyphenols which is ambiguous that their cancer prevention effects may or may not apply in the body. Secondly, the required dose for their effectiveness is also uncertain [53].

\section{Type 2 diabetes}

Research reveals that the risk of type 2 diabetes may be directly decreased by the intake of diet rich in phytochemicals. This is due to the improvement in the sensitivity of insulin and also reducing inflammation. It further helps in stopping obesity indirectly which is considered as the most important risk factor of this illness [54-56]. Inspiring effects on blood glucose level during fasting and insulin sensitivity have been initiated specifically with the consumption of polyphenols revealed by animal studies and laboratory work. Those polyphenols which are part of our diet may constrain digestion of carbohydrate and 
absorption of glucose in small intestine. They also boost insulin secretion in pancreas, control the secretion of glucose from liver, activate insulin receptors and absorb glucose in insulin-sensitive tissues, their signalling pathways as well as gene expression [57]. Certain research reports exposed that by the use of vegetables with green leaves, the reduction of risk is increased due to the presence of phytochemicals in the green leafy vegetables. In a study carried on the Nurses and Health Professionals, it was conveyed that development of type 2 diabetes was at lower risk due to the maximum intake of fruits rich in anthocyanin like onions, coffee, apples, soya beans, tea, citrus fruits and soy products [58]. While in another study about women's health, the relationship between anthocyanin and type 2 diabetes did not link in spite the researchers proposed that the maximum intake of tea and apples have an uncertain risk decreasing effect [59]. The polyphenols found in cocoa and tea may also help in reducing type 2 diabetes risk and improve the sensitivity of insulin. A study carried out in eight countries of continent of Europe about a large population revealed that maximum tea intake decreases considerably the danger of developing type 2 diabetes [60]. It was also reported that those tea users who take more than four cups of tea daily, have $16 \%$ less risk of type 2 diabetes as compared to nontea users. Improved insulin sensitivity, decreased HDL ratio, total cholesterol, LDL cholesterol and reduced insulin level was reported in those diabetes patients who were given chocolate rich in flavonoid and isoflavones supplements in their diet for one year [61]. During a systematic survey, it was conveyed that $26 \%$ low risk of type 2 diabetes was reported in those whose daily intake of whole grains is 48 to 80 grams compared to those who rarely or never take the whole grains in their diet. The same nature of another study conducted in which 161,737 US women having no history of diabetes were investigated. As per the findings of the study, $37 \%$ low risk of type 2 diabetes was reported of those whose daily intake was higher than those with low whole grains intake [62]. The Dietary Guidelines Committee (DGC) (2010) concluded in his report that there is limited indication exists regarding the relationship between the low risk reduction of type 2 diabetes and whole grains intake [63]. But on the other hand, the German Nutrition Society (GNS) determined that there are strong evidences revealing that there is inverse relationship between type 2 diabetes and intake of whole grains [64].

\section{Neurodegeneration}

Secondary metabolites have the ability to provide security against neurodegenerative illnesses such as Parkinson's and Alzheimer's [65]. Latest research disclosed that various phytochemicals have neuroprotective effects like capsaicin (found in red pepper), resveratrol (found in wine, grapes and peanuts), epigallocatechin gallate (EGCG) and curcumin [66, 67]. Similarly, flavonoids are considered supportive during backward declines of age especially in cognitive work by improving the flow of blood to brain and enhancing the number of connections between neurons $[68,69]$ which guards not only susceptible neurons but also promoting the performance of existing neurons. The regular and consistent intake of flavonoids rich diet like cocoa and berries may inhibit normal or abnormal decline in mental function in older age brain and also hold the potential in limits. A number of studies found a connection between the intake of tea and a lesser risk of developing Parkinson's illness or suspending its beginning by several years [70-72]. It has been proposed that the relationship between tea and Parkinson's illness is due to naturally occurring caffeine content. But, another relationship between reduced risk of Parkinson's disease and intake of flavonoids in general and that of berries in particular is also reported [73]. Mixing of particular nutritional flavonoids which are consumed gently and can enter the mind or 
blood barrier (preventing several materials present in blood, from reaching the brain), could treat, support and check different types of neurodegenerative diseases [74]. But still this special type of effective grouping of secondary metabolites has not been reported by the researchers. The intake of flavonoid rich cocoa has been found responsible in the improvement of blood flow in the cerebral portion, which is quite dangerous for the best performance of brain and drops in Alzheimer and dementia's illness $[75,76]$. A research study proposed that the regular and consistent intake of flavonoid rich diets like berries and cocoa may check the cognitive decline and minimize the neurodegeneration to a greater extent. Phytoestrogens, having estrogen like activities are found in grains and soy products, may support cognitive decline that can occur following menopause [77].

\section{Conclusion}

It has been reported by WHO that more than $80 \%$ tribal and rustic people of poor and developing countries rely on phytotherapeutic treatment for their primary health care requirements. It is due to less side effects of herbal medicines, cheap in price and found easily. The therapeutic nature of medicinal plants is due to some biologically active and structurally novel phytochemicals. Which are solely natural and non-essential in a sense not needed by the living organisms but express potency as effective source of medicines needed for healing and safety against herbivores, predators, insects etc. The major metabolic constituents present in medicinal plants are alkaloids, flavonoids, terpenoids, carotenoids, saponins, tannins, sterols, phenolic acids, lignin and stilbenes. Phytoconstituents basically exist in several nutrients however, it is expected that with the help of biotechnology, new plants will be produced that can contain greater number of above constituents. This might fit in sufficient secondary metabolites with our food. Secondly, these phytochemicals will provide proficient role for the development of new drug entities in drug detection and design.

\section{Authors' contributions}

Conceived the idea: A Khan \& M Ayub, Wrote the paper: A Khan, Corrections: $M$ Ayub, Samiullah, M Suleman \& A Baqi, Proof reading: Samiullah, M Suleman \& A Baqi, Correspondence: A Khan.

\section{References}

1. Tiwari P, Kumar B, Kaur M, Kaur G \& Kaur H (2011). Phytochemical screening and extraction: A review. Internationale Pharmaceutica Sciencia 1(1): 98-106.

2. Arica WM, Abdirahman YA, Mawia MA, Wambua KF \& Nyamai DW (2015). In vitro antidiabetic activity of aqueous leaf extract of Croton macrostachyus in Alloxan induced diabetic mice. Pharmceutica Analytica Acta 6(11): 447.

3. Alves TM, Silva AF, Brandao M, Grandi TSM, Smania EFA, Junior AS \& Zani CL (2000). Biological screening of Brazillian medicinal plants. Memorias do Instituto Oswaldo Cru 95(3): 367373.

4. Andrade ECB, Alves SP \& Takase I (2005). Studies on qualitative and quantitative analysis of Cissus quadrangularis. Ciencia e Techniologia de Alimentos 25(3): 591-596.

5. Andrade ECB, Alves SP \& Takase I (2005). Studies on qualitative and quantitative analysis of Cissus quadrangularis. Ciencia e Techniologia de Alimentos, 25(4) 844-848.

6. Prabhavathi RM, Prasad MP \& Jayaramu M (2016). Studies on qualitative and quantitative phytochemical analysis of Cissus quadrangularis. Advances in Applied Science Research 7(4): 11-17.

7. Kalita PP, Sapam R, Sarma MP, Talukdar N \& Das H (2018). Screening of phytochemicals and determination of total phenolic content, antioxidant and antimicrobial activity of methanolic extract of Piper nigrum leaves. Indo American $J$ of Pharma Res 8(2): 13541360. 
8. Cowan MM (1999). Plant products as antimicrobial agents. Clinical Microbiol Rev 12(4): 564-582.

9. Baqi A, Samiullah, Tareen RB, Mengal A, Khan N, Behlil F, Achakzai AKK, Anwer M, Attiq-Ur-Rehman \& Faheem M (2018). Determination of antioxidants in two medicinally important plants, Haloxylon griffithii and Convolvulus leiocaycinus, of Balochistan. Pure Appl Bio 7(1): 296-308.

10. World Health Organization (2002). WHO traditional medicine strategy 2002-2005.

11. Piero NM, Njagi MJ, Kibiti MC, Ngeranwa JJN, Njagi NME, Njue MW \& Gathumbi KP (2012). Herbal management of diabetes mellitus: A rapidly expanding research avenue. Inter $J$ of Current Pharmaceutical Res 4(2): 14.

12. Sisodia R, Verma S, Rani A \& Dureja P (2013). Antibacterial and antioxidant activity of lichen species Ramalina roesleri. Nat Prod Res 27: 2235-2239.

13. Nyami DW, Arika W, Ogola PE, Njagi ENM \& Ngugi MP (2016). Medicinally Important Phytochemicals: An untapped research Avenue. $J$ of Pharmacognosy and Phytochem 4: 35-49.

14. Andrew $\mathrm{B}$ (2017). The chemical composition of green plants. Sciencing Leaf group limited.

15. Ajuru MG, Williams LF \& Anjuru G (2017). Qualitative and quantitative phytochemical screening of some plants used in Ethnomedicine in the Niger delta region of Nigeria. $J$ of Food and Nutrition Sci 5(5):198-205.

16. Ramamurthy V \& Sathiyadevi M (2017). Preliminary phytochemical screening of methanol extract of Indigofera trita Linn. J Mol Histol Med Physiol 2(1): 100011.

17. Samiullah, Alam F, Aslam S, Sajida, Tareen RB, Khan A, Khan N, Akber A, Ali I, Khan AK, Khan MR, Panezai MA, Buzdar MA, Khan SS \& Athiq-urRehman (2017). Determination of chemical composition, total phenolic content and antioxidant activity of
Xylanthemum macropodum. $J$ of the Chem Soci of Pak 39(1): 83-91.

18. Wadood A, Ghufran M, Jamal SB, Naeem M, Khan A, Ghaffar R \& Asnad (2013). Phytochemical analysis of medicinal plants occurring in local area of Mardan. Biochem Anal Biochem 2(4): 2161-1009.

19. Muthukrishnan $\mathrm{S} \&$ Manogaran $\mathrm{P}$ (2018). Journal of Pharmacognosy and Phytochemistry. 7(2): 1955-60.

20. Khalid S, Shahzad A, Basharat N, Abubakar M \& Anwar P (2018). Phytochemical screening and analysis of selected medicinal plants in Gujrat. $J$ of Phytochem and Biochem 2(1): 108.

21. Ncube NS, Afolayan AJ \& Okoh AI (2008).Assessment techniques of antimicrobial properties of natural compounds of plants origin: current methods and future trends. African $J$ of Biotechnol 7(12): 1797-1806.

22. Ishaq MS, Hussain MM, Afridi MS, Ali G, Khattak M, Ahmed S \& Shakirullah (2014). In Vitro phytochemical, antibacterial and antifungal activities of leaf, stem and root extracts of Adiantum Capillus veneris. The Scientific World J 10(1155): 269793.

23. Levine JA (2003). Balanced habits. Retrieved from: https://www1.villanova.edu/content/da $\mathrm{m} /$ villanova/studentlife/documents/healt hpromotion/Phytochemicals\%20$\% 20$ Final.pdf.

24. Heneman $\mathrm{K} \&$ Zidenberg-Cherr $\mathrm{S}$ (2008). Some facts about phytochemicals. UC Cooperative Extension Center for Health and Nutrition Research Nutrition and Health Info Sheet. http://nutrition.ucdavis.edu/content/info sheets/fact-pro-phytochemical.

25. Dauchet L, Amouyel P, Hercberg S \& Dallongeville J (2006). Fruits and vegetable consumption and risk of coronary heart disease: a meta-analysis of cohort studies. J Nutr 136(10): 25882593.

26. He FJ, Nowson CA, Lucas $M$ \& MacGregor GA (2007). Increased consumption of fruit and vegetables is 
related to a reduced risk of coronary heart disease: meta-analysis of cohort studies. J Hum Hypertens 21(9): 717728.

27. Murphy MM, Barraj LM, Herman D, Bi X, Cheatham R \& Randolph RK (2012). Phytonutrient intake by adults in the United States in relation to fruit and vegetable consumption. $J$ Acad Nutr Diet 112(2): 222-229.

28. Andujar I, Recio MC, Giner RM \& Rios JL (2012). Cocoa polyphenols and their potential benefits for human health. Oxid Med Cell Longev 906252.

29. Suzuki Y, Miyoshi N \& Isemura M (2012). Health-promoting effects of green tea. Proc Jpn Acad Ser B Phys Biol Sci 88(3): 88-101.

30. Bahorun T, Luximon-Ramma A, Neergheen-Bhuju VS, Gunness TK, Googoolye K, Auger C, Crozier A \& Aruoma OI (2012). The effect of black tea on risk factors of cardiovascular disease in a normal population. Prev Med 54 Suppl: S98102.

31. Fisher ND \& Hollenberg NK (2006). Aging and vascular responses to flavanol-rich cocoa. J Hypertens 24(8): 1575-1580.

32. Mellen PB, Walsh TF \& Herrington DM (2008). Whole grain intake and cardiovascular disease: a metaanalysis. Nutr Metab Cardiovasc Dis 18(8): 283-290.

33. Ye EQ, Chacko SA, Chou EL, Kugizaki M \& Liu S (2012). Greater whole-grain intake is associated with lower risk of type 2 diabetes, cardiovascular disease, and weight gain. $J$ Nutr 142(7): 13041313.

34. Fardet A (2010). New hypotheses for the health-protective mechanism of wholegrain cereals: what is beyond fibre? Nutr Res Rev 23(1): 65-134.

35. Wang L, Gaziano JM, Liu S, Manson JE, Buring JE \& Sesso HD (2007). Wholeand refined-grain intakes and the risk of hypertension in women. Am J Clin Nutr 86(2): 472-479.

36. Tighe $\mathrm{P}$, Duthie $\mathrm{G}$, Vaughan N, Brittenden J, Simpson WG, Duthie
S, Mutch W, Wahle K, Horgan G $\&$ Thies F (2010). Effect of increased consumption of whole-grain foods on blood pressure and other cardiovascular risk markers in healthly middle-aged persons: a randomized controlled trial. Am J Clin Nutr 92(4): 733-740.

37. Bodinham CL, Hitchen KL, Youngman PJ, Frost GS \& Robertson MD (2011). Short-term effects of whole-grain wheat on appetite and food intake in healthy adults: a pilot study. Br J Nutr 106(3): 327-330.

38. Hui C, Qi X, Qianyong Z, Xiaoli P, Jundong Z \& Mantian M (2013). Flavonoids, flavonoid subclasses and breast cancer risk: a meta-analysis of epidemiologic studies. PLoS One 8(1): e54318.

39. Boeing $\mathrm{H}$, Bechthold A, Bub A, Ellinger S, Haller D, Kroke A, Leschik-Bonnet E, Müller MJ, Oberritter H, Schulze M, Stehle P \& Watzl B (2012). Critical review: vegetables and fruit in the prevention of chronic diseases. Eur $J$ Nutr 51: 637-663.

40. Wakai K, Matsuo K, Nagata C, Mizoue T, Tanaka K, Tsuji I, Sasazuki S, Shimazu T, Sawada N, Inoue M \& Tsugane $S$ (2011). Lung cancer risk and consumption of vegetables and fruit: an evaluation based on a systematic review of epidemiological evidence from Japan. Jpn J Clin Oncol 41(5): 693-708.

41. Aune D, Chan DS, Lau R, Vieira R, Greenwood DC, Kampman E \& Norat T (2011). Dietary fibre, whole grains, and risk of colorectal cancer: systematic review and dose-response meta-aalysis of prospective studies. BMJ 343: d6617.

42. McCullough ML, Robertson AS, Chao A, Jacobs EJ, Stampfer MJ, Jacobs DR, Diver WR, Calle EE \& Thun MJ (2003). A prospective study of whole grains, fruits, vegetables and colon cancer risk. Cancer Causes Control 14(10): 959-970.

43. World Cancer Research Fund/American Institute for Cancer Research (2007). Food, Nutrition, Physical Activity, and the Prevention of Cancer: 
A Global Perspective. Washington, DC: American Institute for Cancer Research.

44. Romagnolo DF \& Selmin OI (2012). Flavonoids and cancer prevention: a review of the evidence. J Nutr Gerontol Geriatr 31(3): 206-238.

45. Juge N. Mithen RF \& Traka M (2007). Molecular basis for chemoprevention by sulforaphane: a comprehensive review. Cell Mol Life Sci 64(9): 11051127.

46. Bondesson M \& Gustafsson JA (2010). Does consuming isoflavones reduce or increase breast cancer risk? Genome Med 2(12): 90.

47. Sak K (2012). Chemotherapy and dietary phytochemical agents. Chemother Res Pract 282570

48. Kaminski BM, Steinhilber D, Stein JM \& Ulrich S (2012). Phytochemicals resveratrol and sulforaphane as potential agents for enhancing the anti-tumour activities of conventional cancer therapies. Curr Pharm Biotechnol 13(1): 137-146.

49. Vinod BS, Maliekal TT \& Anto RJ (2013). Phytochemicals as chemosensitizers: from molecular mechanism to clinical significance. Antioxid Redox Signal 18(11): 1307-1348.

50. Yang CS, Lambert JD, Ju J, Lu G \& Sang $S$ (2007). Tea and cancer prevention: molecular mechanisms and human relevance. Toxicol Appl Pharmacol 224(3): 265-273.

51. Yang CS, Ju J, Lu G, Chung S Yang, Jihyeung Ju, Gary Lu, Hang Xiao H, Xingpei Hao X, Shengmin Sang S, Joshua D \& Lambert JD (2008). Cancer prevention by tea and tea polyphenols. Asia Pac J Clin Nutr 17(Suppl 1): 245-248.

52. Thakur VS, Gupta K \& Gupta S (2012). The chemopreventive and chemotherapeutic potentials of tea polyphenols. Curr Pharm Biotechnol 13(1): 191-199.

53. Martin MA, Goya L \& Ramos S (2013). Potential for preventive effects of cocoa and cocoa polyphenols in cancer. Food Chem Toxicol 56: 336-351.
54. Gonzalez-Castejon M \& RodriguezCasado A (2011). Dietary phytochemicals and their potential effects on obesity: a review. Pharmacol Res 64(5): 438-455.

55. Cooper AJ, Forouhi NG, Ye Z, Buijsse B, Arriola L, Balkau B, Barricarte A, Beulens JW, Boeing $\mathrm{H}$ \& Büchner FL et al. (2012). Fruit and vegetable intake and type 2 diabetes: EPICInterAct prospective study and metaanalysis. Eur J Clin Nutr 66(10): 10821092.

56. Carter P, Gray LJ, Troughton J, Khunti K \& Davies MJ (2010). Fruit and vegetable intake and incidence of type 2 diabetes mellitus: systematic review and meta-analysis. BMJ 341: c4229.

57. Hanhineva K, Torronen R, Bondia-Pons I, Pekkinen J,Kolehmainen $\mathrm{M}$, Mykkänen H \& Poutanen K (2010). Impact of dietary polyphenols on carbohydrate metabolism. Int $\mathrm{J} \mathrm{Mol} \mathrm{Sci}$ 11(4):1365-1402.

58. Wedick NM, Pan A, Cassidy A, Rimm EB, Sampson L, Rosner B, Willett W, Hu FB, Sun Q \& Rm VD (2012). Dietary flavonoid intakes and risk of type 2 diabetes in US men and women. Am J Clin Nutr 95(4): 925-933.

59. Song Y, Manson JE, Buring JE, Sesso HD \& Liu S (2005). Associations of dietary flavonoids with risk of type 2 diabetes, and markers of insulin resistance and systemic inflammation in women: a prospective study and crosssectional analysis. J Am Coll Nutr 24(5): 376-384

60. The InterAct Consortium. Tea consumption and incidence of type 2 diabetes in Europe: the EPIC-InterAct case-cohort study (2012). PLoS One 7(5): e36910.

61. Curtis PJ, Sampson M, Potter J, Dhatariya K, Kroon PA \& Cassidy A (2012). Chronic ingestion of flavan-3-ols and isoflavones improves insulin sensitivity and lipoprotein status and attenuates estimated 10-year CVD risk in medicated postmenopausal women with type 2 diabetes: a 1-year, double-blind, 
randomized, and controlled trial. Diabetes Care 35(2): 226-232.

62. de Munter JS, Hu FB, Spiegelman D, Franz M \& Van Dam RM (2007). Whole grain, bran, and germ intake and risk of type 2 diabetes: a prospective cohort study and systematic review. PLoS Med 4(8): e261.

63. Webb D (2013). Phytochemicals' Role in Good Health. Today's Dietitian 15(9): 70.

64. Hauner $\mathrm{H}$, Bechthold $\mathrm{A}$, Boeing $\mathrm{H}$, Brönstrup A, Buyken A, LeschikBonnet E, Linseisen J, Schulze M, Strohm D \& Wolfram G (2012). Evidence-based guideline of the German Nutrition Society: carbohydrate intake and prevention of nutrition-related diseases. Ann Nutr Metab 60 (Suppl 1): $1-58$

65. Lee JG, Yon JM, Lin C, Jung AY, Jung KY \& Nam SY (2012). Combined treatment with capsaicin and resveratrol enhances neuroprotection against glutamate-induced toxicity in mouse cerebral cortical neurons. Food Chem Toxicol 50(11): 3877-3885.

66. Davinelli S, Sapere N, Zella D, Bracale R, Intrieri M \& Scapagnini G (2012). Pleiotropic protective effects of phytochemicals in Alzheimer's disease. Oxid Med Cell Longev: 386527.

67. Mythri RB \& Bharath MM (2012). Curcumin: a potential neuroprotective agent in Parkinson's disease. Curr Pharm Des 18(1): 91-99.

68. Spencer JP (2009). Flavonoids and brain health: multiple effects underpinned by common mechanisms. Genes Nutr 4(4): 243-250.

69. Williams RJ, Spencer JP (2012). Flavonoids, cognition, and dementia: actions, mechanisms, and potential therapeutic utility for Alzheimer disease. Free Radic Biol Med 52(1): 3545 .
70. Kandinov B, Giladi N \& Korczyn AD (2009). Smoking and tea consumption delay onset of Parkinson's disease. Parkinsonism Relat Disord 15(1): 41-46.

71. 71. $\mathrm{Hu} \mathrm{G}$, Bidel $\mathrm{S}$, Jousilahti $\mathrm{P}$, Antikainen R \& Tuomilehto J (2007). Coffee and tea consumption and the risk of Parkinson's disease. Mov Disord 22(15): 2242-2248.

72. Tanaka K, Miyake Y, Fukushima W, Sasaki S, Kiyohara C, Tsuboi Y, Yamada T, Oeda T, Miki

T, Kawamura N, Sakae N, Fukuyama H, Hirota Y \& Nagai M (2011). Intake of Japanese and Chinese teas reduces risk of Parkinson's disease. Park Relat Disord 17(6): 446-450.

73. Gao X, Cassidy A, Schwarzschild MA, Rimm EB \& Ascherio A (2012). Habitual intake of dietary flavonoids and risk of Parkinson disease. Neurology 78(15): 1138-1145.

74. Jones QR, Warford J, Rupasinghe HP \& Robertson GS (2012). Target-based selection of flavonoids for neurodegenerative disorders. Trends Pharmacol Sci 33(11): 602-610.

75. Fisher ND, Sorond FA \& Hollenberg NK (2006). Cocoa flavanols and brain perfusion. J Cardiovasc Pharmacol 47(2): S210-S214.

76. Francis ST, Head K, Morris PG \& Macdonald IA (2006). The effect of flavanol-rich cocoa on the fMRI response to a cognitive task in healthy young people. $J$ Cardiovasc Pharamcol 47 Suppl 2: S215-S220.

77. Zhao L, Mao Z \& Brinton RD (2009). A select combination of clinically relevant phytoestrogens enhances estrogen receptor beta-binding selectivity and neuroprotective activities in vitro and in vivo. Endocrinol 150(2): 770-783. 